\title{
Interfaces and divisions in the Dublin Docklands 'Smart District'
}

\author{
Liam Heaphy \\ NIRSA, Maynooth University, County Kildare, Ireland
}

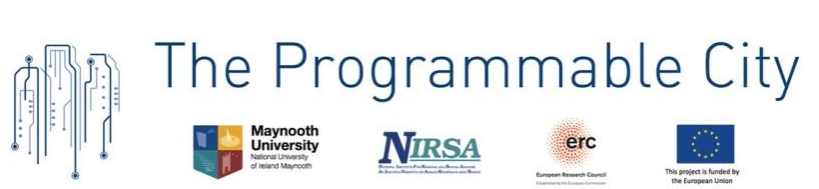

The Programmable City - Working Paper 37

http://progcity.maynoothuniversity.ie/

12 January 2018

Published as an open access pre-print on SocArXiv: https://osf.io/preprints/socarxiv/z2afc

\begin{abstract}
The study of physical and social divisions in divided societies has long been an area of study, such as the continued usage of 'peace walls' in Belfast, hostile architecture to prevent antisocial behaviour and rough sleeping, and the securitisation of private spaces. In the context of a new drive to create a smart district, this paper looks at the relationship between smart urbanism and planning, and at the spatial and social divisions between a new 'gentrifying' and well-educated community in the Dublin Docklands and established communities in the area. The Dublin Docklands redevelopment marks a significant break from a pattern of suburbanisation and inner-city decline and repurposes part of the former port area as a city centre extension. The paper accounts for the reshaping of the Dublin Docklands as a 'smart district' in collaboration with the city authorities, based on over thirty semi-structured interviews and participant-observation at consultation events. It argues that reductive definitions of smart cities as networking technologies be reworked into broader considerations on urban technologies and the future of cities, with greater emphasis on the relationship between technologies branded as 'smart' and the material and digital manifestation of boundaries in urban form.
\end{abstract}

Keywords: smart urbanism, smart cities, ports, planning, technology, urban design, interfaces, boundaries 


\section{Introduction}

What relation do so-called smart city technologies have to urban form? In what ways can they reconfigure social relations and create new boundaries or connections between citizens? Having enquired empirically into the means by which smart technologies interact with urban form, can we then normatively and ethically define 'smart urbanism'? While many scholars have questioned its dominant logics (Calzada and Cobo, 2015; Kitchin, 2014; Marvin et al., 2016), few have developed alternative visions (McFarlane and Söderström, 2017) or frameworks thus far that go beyond essential critique and empirical detail.

Critical urban geographers have appealed to the durability of neo-Marxist critique for analysing urban change and uneven development (Brenner et al., 2011), while Farías and Blok (2016: 2) argue that assemblage urbanism can look towards "reimagining the city as a multiple object-space", thereby opening the path to new forms of imagining the city. Adhering to actor-network theory as a means of tracing assemblages, they follow Latour (2013) and Stengers (2005) inasmuch as they have sought to move beyond emancipatory deconstruction towards new forms of reconstituting shared spaces. For Latour, this led to an experimental project that sought to detect and collectively institutionalise 'modes of existence' (Gilbert Simondon, 1958), stimulated by a hope of reconciling humanity, technology, and the environment. Similarly, Farías and Blok call for a cosmopolitics of assemblages and atmospheres "for reimagining and re-practising the city" (Farías and Blok, 2016: 242). In this sense, assemblage urbanism returns to the shared core values of science and technology studies, seeking to understand entanglements and 'slow down' science so that democratic participation and oversight might be increased. While not necessarily dystopian, it places an ethical importance on showing how the social is entangled with the scientific, occasionally negatively associating science itself with epistemological realism (Boyd, 1990; Giere, 2005) and leading to the 'science wars' that are already well described (Fuller, 2012; Lynch, 2012; Zammito, 2004). As Guggenheim notes (2016), there was no such acrimony about the co-constitutive role of the social in architecture, where its ethnographic and relational approach to understanding buildings and urban form has been extended by scholars with roots in science and technology studies (Houdart and Minato, 2009; Yaneva, 2009).

This paper originates from the desire to make a modest contribution towards a normative perspective on smart urbanism from a social sciences perspective, based on research into 'smart districts' or 'innovation districts' and dockland redevelopment. It draws on socio- 
technical studies of 'hostile architecture' (Petty, 2016) and defensive planning in conflict contexts (Dawson, 1984; Brand, 2009; Murtagh, 2011) such as Belfast where social and political divisions are recognisably manifested in urban space, as well as on the politics of design (Yaneva, 2017).

It is maintained here that further studies on smart districts and urban form will benefit from attention to how physical, social, and digital infrastructure interact in urban space, creating partly isolated pockets and communities, as well as studying the interfaces between them. To this extent, it resembles studies on uneven development and global capitalism inasmuch as it looks at the forces and influences shaping urban life in a docklands city development, but instead draws primarily from assemblage theory (Farías and Bender, 2012) and science and technology studies as applied to urban form (Latour, 2005; Yaneva, 2017). This involves an emphasis on ethnographic observation and the formation of neo-empiricist thick descriptions that trace the associations between actors, both human and non-human. Therefore, while other studies such as Byrne (2016) have attentively looked at capital flows and investment, this paper seeks to make a modest contribution instead through ethnographies and participant-observation with greater attention to localised flows and interactions.

The discussion maps out two definitions of smart city: one narrower definition focussed on sensors, networking technologies and ubiquitous computing, and a second looser definition where the 'smart city' can be seen as a 'floating signifier' (Mehlman 1972). This latter term was used in anthropology by Lévi-Strauss (Mehlman, 1972) in relation to the paradox that to understand the sauvage, the Western anthropologist would strip the object of their savagery. This necessitated common signifiés which in turn requires a common world, which he believed existing in the subconscious and manifested in the body. In the case of our smart cities, there are few first encounters, and instead we can attribute the floating or open nature of smart cities to it being part of a wider debate on the future of cities, as well as to the competitive jostling for primary positions between city administrations. The narrower definition, when allied to a newer population of high-skilled mobile workers and wedded to entrepreneurial urbanism, may reinforce existing inequalities, whereas the second definition opens up to a broader agenda of place-making and sustainable urbanism, creating the conditions for smart technologies to be rolled out on communal infrastructure. Therefore, from a normative perspective, this paper also argues for smart districts to be closely aligned with place-making and consensual planning models, which may deflect part of its familiar 
criticism as being a further agent of neoliberalism (Kitchin et al., 2017; Marvin et al., 2016; Shelton et al., 2015).

The case study, the Dublin Docklands, is the site of one of the largest urban redevelopment programmes in the Republic of Ireland, running under various guises from the early 1980s through to the present day, following and reflecting the changing economic fortunes of the State. It exists both as an important national signifier of modernity, and locally, as the logistical centre of imports and exports that once employed thousands of labourers prior to mechanisation. Much of the docklands is now an extension of the city centre, with a large financial services centre and cultural institutions, displacing the main thoroughfares as the photographer's choice location for marketing material.

Fieldwork was based on thirty semi-structured interviews as part of a Dublin City Council-led stakeholder scoping project for their incipient smart district, and shared between two research projects. ${ }^{1}$ The author also conducted additional fieldwork interviews in Cork (3) and Boston, Massachusetts (7) in terms of their own waterfront development programmes, which combine to 48 interviewees over the course of forty separate interviews. Participantobservation was also conducted within an URBACT smart districts project called SMARTImpact, a network of 10 European cities including Dublin and led by Manchester $(\mathrm{UK})^{2}$

The following section expands on the basis for restricted and expanded definitions of the smart city based on the literature and semantic analysis of journal articles, before then charting the recent urban development history of the Dublin Docklands in Section 3. Thereafter, the 'hard' and 'soft' urban technologies and divisions which characterise the Docklands, as well as those highlighted by interview participants in relation to its place as a smart district, are analysed in Section 4. The penultimate and final sections then consider the implications for 'smart urbanism' inasmuch as the 'smart city' might be enrolled into sustainable, design-led urbanism with consideration for more equitable participation.

\footnotetext{
${ }^{1}$ The research in Dublin was collaborative and shared with Maynooth University Business School, with 27 of the 30 interviews conducted with or by Réka Péterscák.

${ }^{2}$ URBACT projects are funded by the European Regional Development Fund and administered by the European Territorial Cooperation programme. As noted by Kitchin et al. (2017), the objectives of URBACT align with an epistemic community of smart city technologists and advocates, through facilitating exchange of best practices and the capacity-building for sustainable urban development in Europe.
} 


\section{The future of the city or merely a new generation of networking technologies?}

The term 'smart' as applied to cities has been in existence for several decades, at least as far back as the World Forum on Smart Communities in 1997 (Hollands, 2008: 304). It acquired greater currency as part of IBM's Smarter Cities programme in 2010, building on a shared consensus among policy and business elites that cities needed to advance themselves further in order to appeal to inward investors, as well as seeking opportunities in the great new cities of East Asia (Cullen, 2016; Wiig, 2015). This was part of their technical consultancy offer to cities, building on the continued digital drive and the desire for efficiency in a time of global economic crisis.

The 'smart city' alternates between reductive descriptions of integrated and partly or fully automated systems, and as a vehicle for broader societal and civic objectives. Where the technology-dominated concept veers towards the Internet of Things and big data, the original idea returns to digital civic spaces and increased contact and efficiency between citizens and citizen-interest representatives such as city councils. A search of journal articles in Scopus bearing the term ["smart city" or "smart cities"] reports 1,911 journal articles, the majority of which are in the applied sciences. When placed on a timeline, there is a drastic upturn in production from 2010 (8 documents) through to 2017 (594 documents). Visualised in Figure 1 as a title and abstract keyword analysis in VOSviewer (from Leiden University), this corpus reports central clusters of networking architecture on one side, and economic innovation policies with links to urban planning and social critique on the other. 


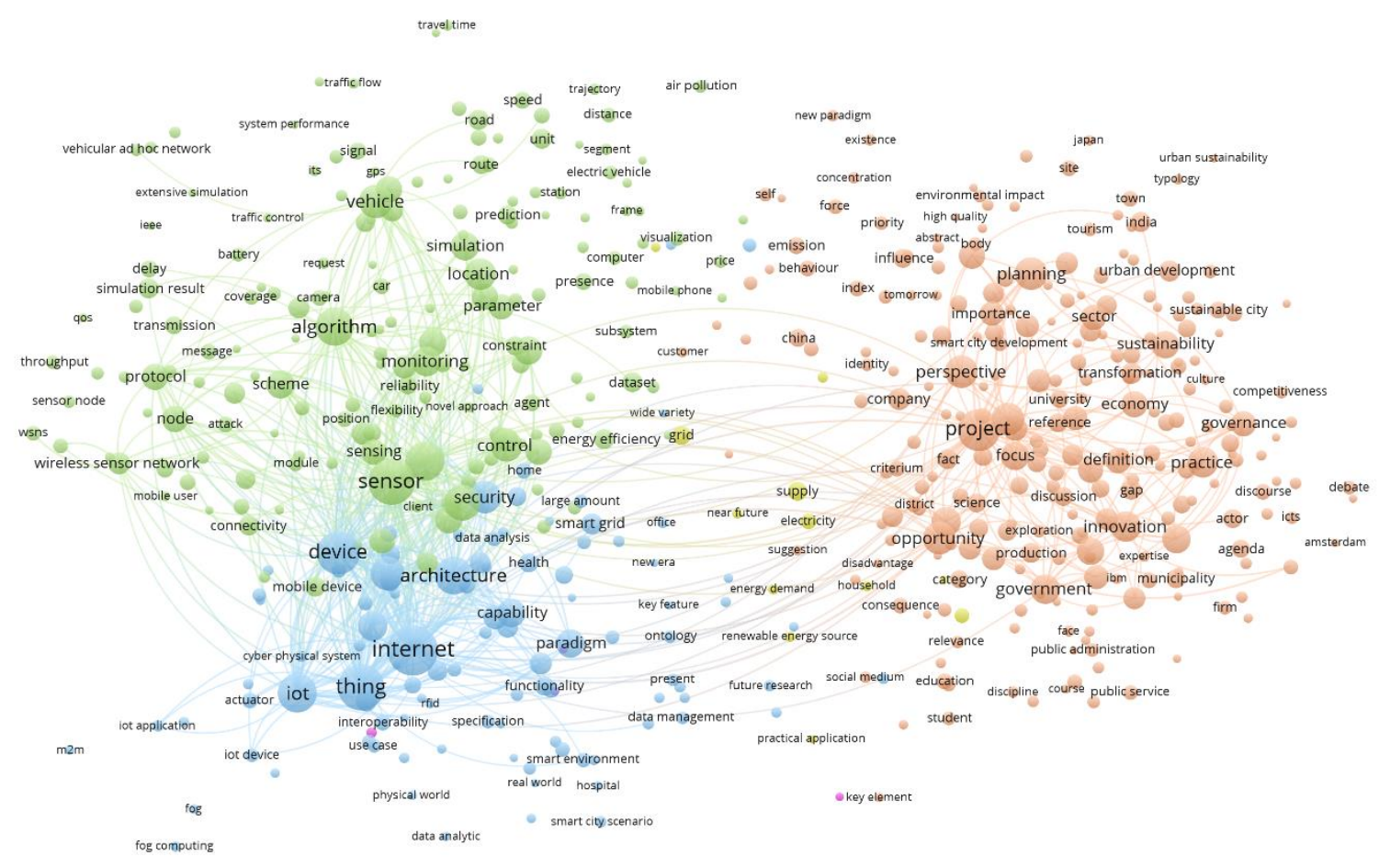

Figure 1: 1,911 published journal articles from Scopus imported into VOSviewer and analysed visually for co-occurrence of keywords in titles and abstracts.

As per the aforementioned 1997 World Expo, the term 'smart communities' is once again in popular discourse through European programmes such as the H2020 Smart Cities and Communities funding call. A citizen-centric discourse is also maintained through the oft-cited and timely report on medium-sized European smart cities (Giffinger and Pichler-Milanović, 2007), which created a frequently-used classification scheme encompassing the citizenry, environment, and quality of life (Caragliu et al., 2011; Coletta et al., 2017). Nevertheless, in the semantic network (Figure 1), neither citizens nor communities emerge as frequent terms. Rather, it seems that the harder definition of smart cities apparent in the literature softens and loosens a little once it comes into contact with planning and civic cultures, where it is heavily linked with sustainable economic development and innovation. The term has extended throughout the Middle East and East Asia (Cugurullo, 2016, 2017) and India (Datta, 2015).

\subsection{Cosmopolitanism and peripherality in relation to smart city definitions and urban form}

The increasing amount of contact between smart city research groups and urban administrations allows researchers to acquire first-hand detailed accounts of how the "smart city' is embedded into civic cultures. For this reason, it may be useful to situate Dublin not only as a port city, but also as a global cosmopolitan city, whereby its port heritage and importance as a medium-sized national capital brings the core smart city concept into contact 
with an urban culture. In the absence of this urban and intellectual culture, the smart city may become operationalised in a less contentious and rather practical, instrumental manner.

Provincial cities that primarily serve their hinterlands, without highly developed functions of mercantilism, artistic production, and intellectual endeavour, are likely to embrace a narrower model of the smart city. Illustrative of this, perhaps, is Opelika, Alabama, a small city of 29,869 (www.census.gov) adjoined to the larger city of Auburn. While the CTO has duly consulted smart city frameworks and formed a quadruple helix framework to integrate government, academia, industry, and society, the essential core remains focussed on networking infrastructure (Dawe and Paradice, 2016; Dawe and Sankar, 2016). These encompass new LED smart lighting infrastructure piggybacked with video and analytics for traffic, drainage, and speed observation, rolled out without notable incident according to the CTO, save for occasional gunshots at the cameras believing they were for traffic enforcement, rather than data analysis. The city features a mixture of new world vernacular architectural forms, and low-density single plot housing, centred on a central wide strip through which a railroad passes. Its name means "large swamp" in Muscogee, the language of the native American people forcibly expelled to what became Oklahoma in the early 19 th century.

In contrast, Barcelona is a cosmopolitan European port city with a long pedigree of artistic and mercantilist endeavour, from the Llibre Vermell de Montserrat to the pioneering urban planning and modernism of Cerdà and Gaudí. It has undergone consistent and rapid urban development since the fall of the Francoist regime, and is regularly mined for its best practices (Hebbert, 2006). As home to the annual World Expo on Smart Cities, it has a mature smart cities programme (March and Ribera-Fumaz, 2016) which in addition to developing a common technical standard (Sentilo) for smart city sensing, created an innovation and technology zone called District 22@ in the early 2000s in the old working quarter of Poblenou, and more recently, a landmark smart building, Media-ICT. Most distinctively, it has integrated the smart city layer into its concept of illes autosuficients. Its former chief city architect, Vicente Guallart, has incorporated ideas from urban ecology and sustainability science into his concept of self-sufficient cities (March and Ribera-Fumaz, 2016: 819), where the city becomes a low-carbon resilient system of systems, and producer of energy and food (Guallart, 2012). It focuses on tight urban grain facilitating minimalised transit ('slow cities') while integrated into intensive data networks of high velocity. 
March and Ribera-Fumaz (2016: 826) provide a critique on the depoliticising nature of technology in the case of Barcelona and consider that without inclusivity of the citizenry and with over-representation of corporate power, the 'smart city' may become "an empty, hollow signifier". However, this is perhaps at risk of glossing over the clear place of the smart city in its current phase of urban renewal, which looks at neighbourhood provision and selfsufficiency (Casamor Maldonado, 2016). It has sought to build on its long-term urban revitalisation with an economic innovation programme that would raise its relatively low per capita GDP, strengthening links between academia and industry (COMPETE, 2006) and removing its overdependence on tourism with its attendant ills (Casamor Maldonado, 2016). Its urban renewal work has continued apace, with a detailed approach to place-making and neighbourhood vitality which ensures public services are within walking distance for all citizens. Following the election victory in 2015 of Mayor Ada Colau and her party, Barcelona en Comú, the city is now undergoing significant change due to a focus on technical sovereignty and citizen platforms (Calzada, 2017).

While both Opelika and Barcelona have implemented similar smart sensing infrastructure, the relation to urban form is more apparent in the latter city, which has pioneered an innovation district and supported the construction of landmark buildings. The city is a stage for urban experimentation and innovation, and a hotbed for radicalism and urban subcultures. At present, it is the scene for resurgent Catalan nationalism, yet nationalism itself is also contested and mediated through the internal civic and urban machinery of the city itself. Its squares large and small, cafés, avenues, and intellectual institutions do not instinctively recoil from contestation out of fear and insecurity. Its denizens share a civic space, with strong spatial connectivity across a network of selfsufficient urban quarters.

\section{The docklands as a testbed for urban technologies}

Ireland, throughout its modern history, has served a testbed for colonial and imperial administrations in the British Empire, with Dublin as the enforced centre of power and emblematic of Ascendency rule in Ireland (Kincaid, 2006). Consequently, as the Republic of Ireland approaches a century as a de jure independent European nation-State, the city has had a complex relationship to a State that originally championed a rural ethos, depopulating the city centre as slums were cleared and more generous housing provision was created in new suburbs. While efforts were made to safeguard the city's rich neoclassical and Georgian 
architectural legacy, much of the largest building efforts championed internationalism and modernism as the template for the new State. In the case of power centres like the Central Bank and the Dublin City Corporation civic offices, both designed by architect Sam Stephenson, new structures rose over the old city and asserted the new power structures in place. Landmark buildings were frequently brutalist or modernist, contrasting with their urban environment or rustically situated in open ground. However, during the 1980s and 1990s, a new generation of Irish architects would place greater importance on urban grain and vitality, defending the serendipity of cosmopolitan urban spaces, with a common focus on the 'European City' (Lawton and Punch, 2014). For new urban projects like Temple Bar and the second phase of the IFSC development in the Docklands, the new European ideal of design involves mixed use, compact, urban development with greater concern for the locus urbis of communal living in a valued space (Rossi, 1982).

The Docklands development was also particularly driven by greater demand for highgrade office space in the city, as Ireland's embrace of industrialisation and foreign investment from the 1960s began to bear greater fruits. The Republic's selective approach to modernity necessitated careful experimentation with globalisation, leading to the success of the Shannon Free Trade Zone as a pioneering site for contained globalisation. The government later repurposed its enterprise zone model towards urban development with tax incentives for potential tenants through the Urban Renewal Act in 1986 (O'Leary, 2014: 162). This early phase of development, encompassing the Custom House and its immediate eastern environ, resembles the forms of entrepreneurial urbanism (McGuirk and MacLaran, 2001) previously enacted in the docklands of London and Melbourne (Moore, 2008: 57; Byrne, 2016) and across the European continent (Swyngedouw et al., 2002). The development sought wholesale mixed-use redevelopment with an appeal to an urbane and lucrative clientele through cultural attractors such as exhibition spaces and restaurants.

\subsection{Development of the docklands until the financial crisis}

The first phase of development, managed by the Custom House Docks Development Authority (CHDDA) and reporting directly to the Minister of the Environment, was characterised by its defensive planning and corporatised publicly-accessible private spaces (Lawton and Punch, 2014: 875). It also began with an offensive manoeuvre, signed off by the Minister for the Environment in 1989, that sought to demolish the Sherriff Street public housing flats in favour of population replacement, with existing residents to be scattered 
across the city in other housing projects. The local population mobilised in resistence, hearings were given in the Dáil (Parliament) and Seanad (Senate), and 113 local authority units were completed locally for existing residents (Punch, 2006: 195).

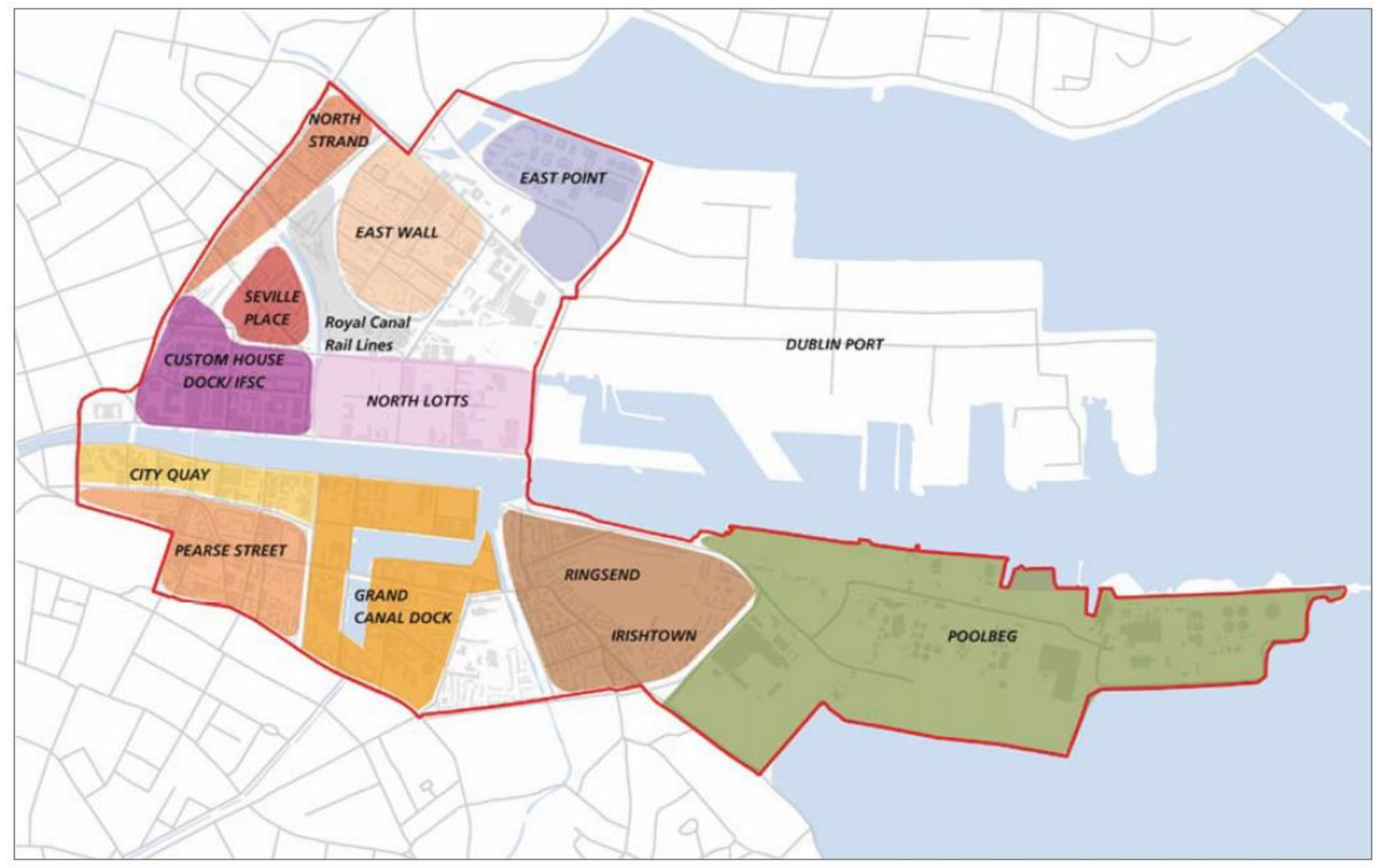

Figure 2: DDDA 2008 Masterplan of the full area for development with local placenames (Sheriff Street is located within the area marked Seville Place).

In 1994, the CHDDA area was extended to include the former site of the 18 blocks of flats, then again in 1997, when the new Dublin Docklands Development Authority was established to cover a 526-hectare site encompassing both the entire repurposed docklands area and its neighbouring established communities. This phase of development marked a shift in urban planning, with a strong design focus and many architects employed in the planning team. It integrated social concerns through the provision of employment and training programmes for local communities and the provision of new social infrastructure. The DDDA featured a Council of 25 members drawn from the local communities, which oversaw the implementation of the masterplan and provided recommendations to the Executive. This latter body featured representatives from the banking and development sectors, whose members would later be implicated in the spectacular banking collapse, with its material manifestation being the former modern ruins of the defunct Anglo-Irish Bank on the North Wall in which the Central Bank has now taken residence. 
The DDDA was also a testbed for new social policies, including a $20 \%$ affordable housing requirement, and higher minimum standards for apartments strengthening the provision of space, light, storage, and access. The social and affordable housing target was partly met with housing away from the main area of urban development. Nevertheless, social housing provision was created in mixed tenure schemes in several parts of this new development with street-level access and no variation in standards. It is in recent mediumscale planning projects such as the Dublin Docklands, and latterly with peri-urban sites such as Adamstown, that the city has taken to integrated total planning of infrastructure and mixed-use compact urban development, even as it continued down the path of entrepreneurial urbanism set down by its precedents (Bartley, 2007; MacLaren et al., 2014).

\subsection{Crisis and renewal facilitating the 'Silicon Docks' and 'Smart Docklands'}

The Dublin Docklands Development Authority (DDDA) was responsible for strategic planning and urban design principles until 2012, when its functions were restored to Dublin City Council (Moore, 2012). This event had followed a severe combined banking and housing crisis which had precipitated an EU and IMF bailout of the country's finances following exposure of the systematic failure of the banking sector, resulting in much of the final phases of development being shelved. A bad debts holding entity was created called the National Assets Management Agency (NAMA), to which bankrupt developers had to submit their failed urban projects (Byrne, 2016: 6). Dublin City Council then prepared a new master plan for a scaled-down area encompassing the remaining undeveloped centrally-located sites using a new planning vehicle called a Strategic Development Zone (SDZ). This replicates part of the planning regalia of the DDDA but with direct oversight from the City Council rather than a corporate body. This new boundary excluded the existing communities previously within the 526-hectare DDDA, focussing instead on those sites previously covered by the fast-track planning Section 25 certificates as detailed in the Act and deemed of particular national importance (Rialtas na hÉireann, 1997):

\footnotetext{
Well I think one of the justifications for the boundaries is the SDZ legislation, because it is such an unusual piece of law that you avoid An Bord Pleanála, it should be a very tightly used thing, it should be rarely used actually because the minister can only designate it if he says there is something nationally important here. So his view was this is the core of the city, if we get this right and get it done quickly we can generate all sorts of activity employment, revenue and so on. (Interview SDD27, NAMA)
}

NAMA are required to claw back funds to the Exchequer, and the quote above reflects their primary mission of well-managed urban development to gain the best possible financial 
benefit from the toxic debts it has inherited from the nationalised banks. ${ }^{3}$ This boundary change has altered the planning process in the Docklands, with less stipulation for direct community investment resulting from planning gain levies on developers, and instead favouring general infrastructure.

I don't think we are going to have as much control, any control over the SDZ, the way we had over the Section 25. Because Docklands was on our side, and when planning applications would go in, there was [sic] conditions that had to be met. Now through battling through the consultative forum that the DCC held, we were very, very vocal about the master plan and what was contained around Section 25. And you know when we asked the question what about community infrastructure and community investment, they said oh yeah there will be a levy and all that, but that will go to infrastructure and sewers and lights and roads. So there is now a stipulation in the planning that there has to be some give back, so my vision for Docklands is cohesion. (Interview SDD21, community representative)

Where once it was the DDDA which directly handled investment in social infrastructure, now community workers like that quoted above must look to Dublin City Council departments, perceived as being less accessible and responsive. However, the Council has retained the DDDA site-building and continues the consultative forum.

The reference to cohesion relates to the fact that the new boundaries in the SDZ have singled out a new demographic explicitly linked to the vision of Dublin as a smart city with its own 'Silicon Docks' to rival extra-Californian tech enclaves around the globe. As the masterplan notes, these new "youthful faces" with their "brilliant creative and technical minds" will not be satisfied with "formal, constrained and structured work environments". Therefore:

The SDZ strategy includes an emphasis on creative spaces and 'open houses' for demonstrating and discussing technology. Industry players indicate that 'Cool' needs to meet 'Geek' to ensure organic networking opportunities which will entice new talent and lead to the creation of supplementary companies. (Dublin City Council, 2014: 38)

As a result, the area is home to two communities with distinctive features: one, an established lower and middle-income population with pockets of deprivation and many older residents and children; and two, a new demographic of high-skilled workers in the expanding technology and finance sectors that are typically in their 20s and 30s and pre-family status. While both planners and community workers have stated preferences for integrating communities for their mutual benefit, there are nevertheless stark contrasts in the area manifested not only through demographic contrasts but also in the built environment itself.

\footnotetext{
${ }^{3}$ Nevertheless, NAMA is also being partly repurposed to fill housing objectives that were not part of their original mandate, such as the large housing scheme planned for the adjacent Poolbeg SDZ (itself a purchase made by the DDDA and instrumental in its collapse).
} 
It is within this SDZ that Dublin City Council's 'Smart Docklands' testbed smart district is largely being discussed and prepared although workshops are underway with residents from the wider Docklands Area corresponding to the DDDA. The smart district is both a driver and beneficiary of technological modernisation, given that this land was ceded due to the preceding stages of containerisation and mechanisation of the port, which had opened up similar dockland areas around the world for development from the 1970s and 80s (Verhoeven, 2010). Each technological shift leaves its traces in form and the quotidian experience of urban life, and therefore, before considering the technologies proposed for the smart district it will be pertinent to consider the spatial consequences of previous phases of technological and infrastructural change.

\section{Creating boundaries and managing interfaces with hard and soft urban technologies}

Similar to other waterfront development programmes like those of London and Toronto, the new influx of wealthier, more mobile, residents has placed previously more isolated social groups into closer contact (Moore, 2008: 64) and exacerbated divisions in the inner city (Haase, 2009). These contact points are mediated by pre-existing infrastructure such as industrial boundary walls, railways, waterways, and the port.

\subsection{Dublin Port's strategic shift from organised retreat to urban integration}

Dublin Port is the largest port on the island of Ireland, facilitating the flow of 34.9 million tonnes of cargo in 2016, and one of three base ports along with Belfast in Northern Ireland and Cork on the south coast. It is also home to an expanding cruise ship terminal, necessitating greater logistic fluidity as the flows of the tourist industry operate in close quarters with heavy logistics. Perpetually under pressure to cede territory to residential and office use, and at one point under pressure to relocate the entire port, they have carefully managed their boundaries to preserve both their relative sovereignty yet also their integration and visibility in the city.

A defensive approach had been undertaken by the previous CEO, resulting in the development of the East Point Business Park, an island of mono-zoned generic offices to the north of the East Wall residential community.

So we had been involved in that area, so he [the previous CEO] said let's extend that to the western perimeter of the port, let's build offices here. Let's build a wall of offices that will keep the port separate from any residential developments going on across the way. So his view was let's not integrate with the city, let's operate as we have operated here, let the city worry about itself. There's pros and cons to both arguments. And we have operated 
behind a wall very successfully for a long period of time so you ask the question why are we opening ourselves up and there are very good reasons for doing it. But that was his view so we have completely turned around what our view was. (Interview SDD30, Dublin Port)

Dublin Port has since followed a new strategy in Port-City relations called 'soft values' (Hooydonk, 2007), which favours partial integration with the urban realm and a more multilayered form of interaction beyond logistics (Hoyle, 1989). The modernisation of the port industry removed the need for the casual labour once associated with the local docklands community (O’Carroll and Bennett, 2017), who had to reskill for a far smaller pool of qualified positions. A soft values strategy is a means to halt the resultant social disconnect between the city and its originator; the port as a major trading hub which directly binds the city to both its rural hinterland and external trading partners. Consequently, Dublin Port invests more in heritage and arts projects, including the restoration of a 1950s crane at the entrance to the port, and the restoration and relocation of the Diving Bell (once used for dry underwater construction) to Sir John Rogerson's Quay. In addition, access to the Port Centre building has been remodelled and opened via a new publicly accessible plaza and the softening of the boundary wall with artfully rusted iron (McDonald, 2017), with plans also for a cycleway along the northern perimeter. 


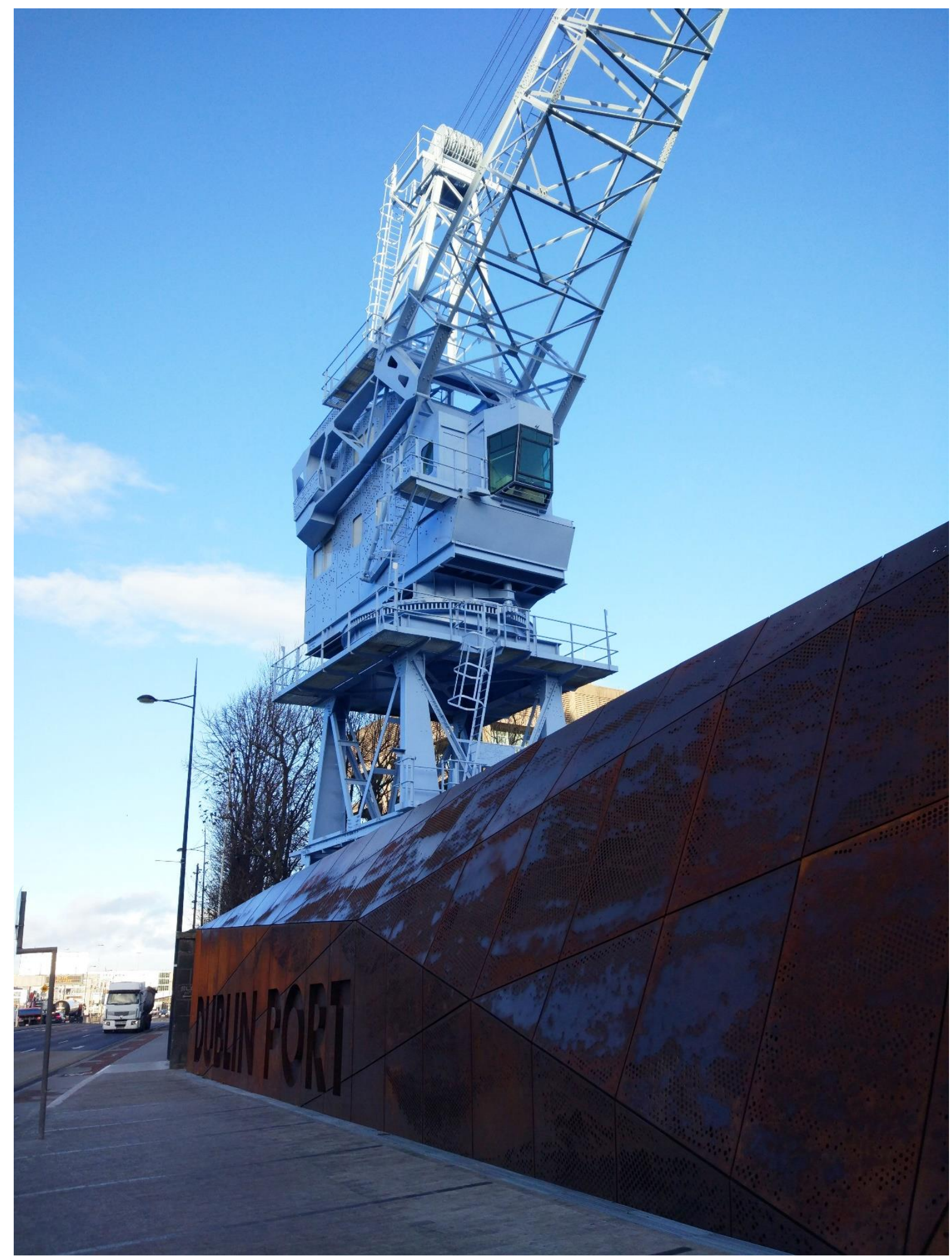

Figure 3: Restored crane and corten steel panels at entrance to port (source: author).

Dublin Port is a stakeholder with the smart districts programme and collaborating with Dublin city to prepare bids for EU funding, which thus far includes testing autonomous electric vehicles. In contrast, a continental port like Rotterdam, with a throughput of 461.2 
million tonnes in 2016, forms a major component of the city's economy with a giant industrial footprint. The Port of Rotterdam invests in start-up initiatives and is in the process of creating an innovation district within the port, where the industrial space of the port may suit certain technology start-ups (Witte et al., 2017). No such plans currently exist for incubators within the far smaller Dublin Port, but the redeveloped docklands contain several adjacent incubators including Dogpatch Labs, DoSpace, and the Docklands Innovation Park.

\subsection{Peace-walls and a new generation of digital divides}

Sheriff Street, a name so associated with inner city problems in popular discourse that they have considered renaming it, is adjacent to the earliest phases of development in the Docklands. The developers retained and repurposed a 9m high granite 'peace-wall' along the length of Common Street, to which netting was added to detain missiles en route to the new upmarket flats on the other side.

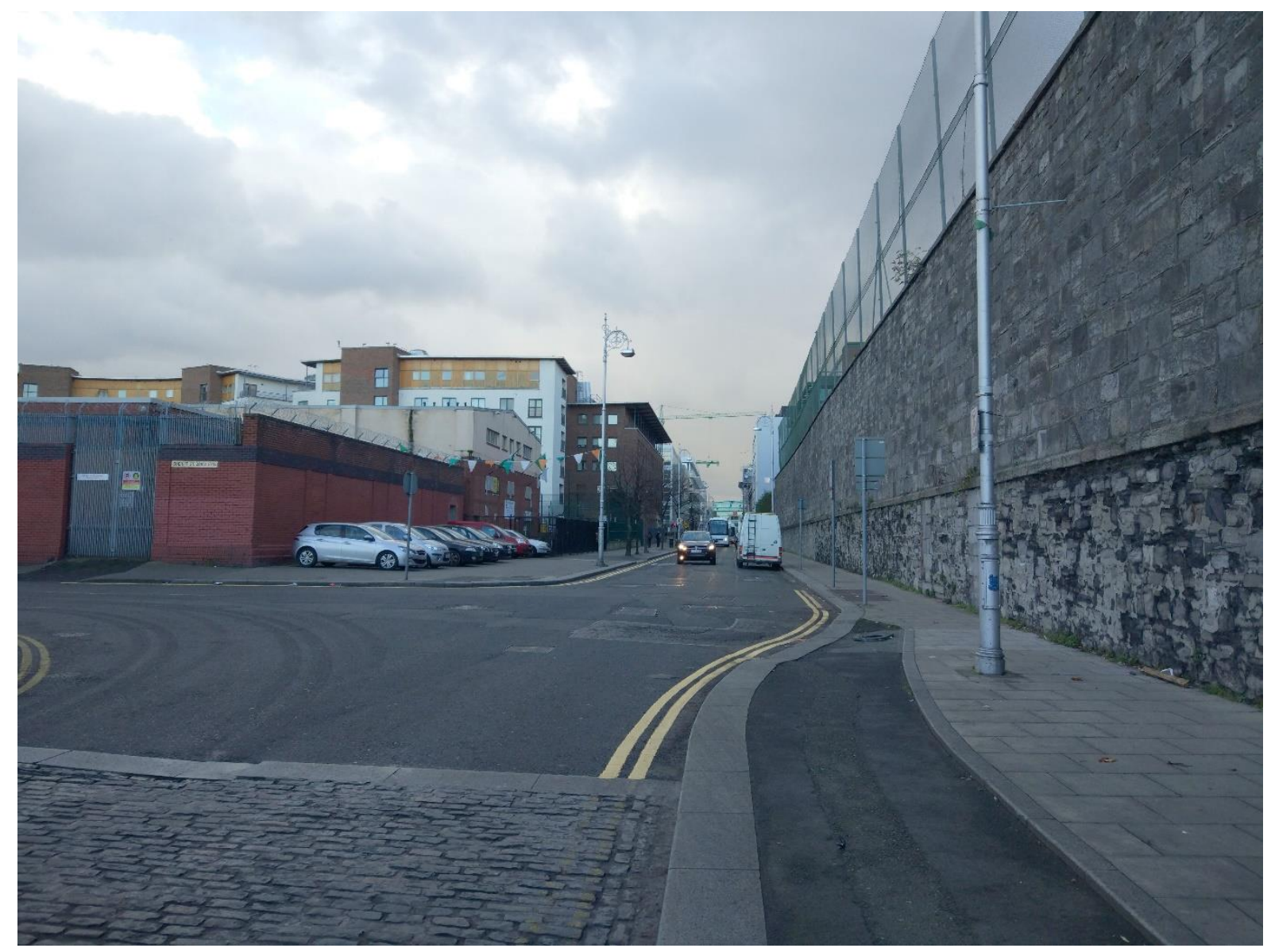

Figure 4: Boundary on Common Street (looking South) between North Wall social housing and private housing on St George's Quay (source: author).

Whereas in Belfast, the actual 'peace-walls' both reflect and arguably reinforce sharp sectarian divisions (Murtagh, 2011), Dublin instead has repurposed industrial heritage to 
separate social classes. Unlike its northern neighbour, Dublin was not riven by sectarian conflict at the street or neighbourhood scale, and its largely dissolved or subdued religious and political divisions represented themselves at the township scale (Maguire, 1993; Wallace, 2017). Yet manifestations of division can be frequently subtler than walls, and Belfast itself has been subjected to minor rearrangements that manage and maintain divisions without walls. These forms of defensive planning (Dawson, 1984) can also take the form of sports grounds and office blocks that act as buffers between clashing urban spaces with key access points heavily regulated or indeed closed (Gaffikin et al., 2016).

Social divisions linked to entrepreneurial development with resultant gentrification have long been an occupation for geographers (Harvey, 2002). In Sheriff Street, as much as anywhere else, these contrasts are manifested in spatio-temporal rhythms, with the majority of office workers spilling out and commuting home after work.

It is like watching a Michael Douglas movie, Wall Street, things were good but I think
what I always found fascinating is how much you were reminded of how good things were
for you and you looked out of your window and you could see Sheriff Street. People didn't
really like that right outside their back door when they were looking to enjoy the fruits of
their labour and their success. People never really come down. When you are in the IFSC
it is all very much geared towards going straight down, there is nothing about turning to
the left to come down Common Street. You just never did, I never did. Coming for the
interview here was the first time I walked down Sheriff Street. (Interview SDD31,
community worker)

Sheriff Street is also buffered from the newer developments by a long series of sport grounds (Harding, 2002), as well as the Royal Canal and railway line into Connolly Station. It is adjacent to the East Wall community, which is almost completely enclosed by rail and port infrastructure. An interviewee from the East Wall (SDD28, community worker) reported that plans to connect the areas east and west of the Royal Canal beside the Convention Centre had been resisted by local residents fearing anti-social behaviour. At the intra-community scale, the same interviewee talked of the need for street furniture, such as benches for the elderly, to be designed to maintain those spaces free from the anti-social behaviour of local youths.

A further divide is that of access to broadband, with existing communities having less household access to the internet (Figure 5). This correlates closely to socio-economic status and where low-income and social housing blocks are concentrated. 


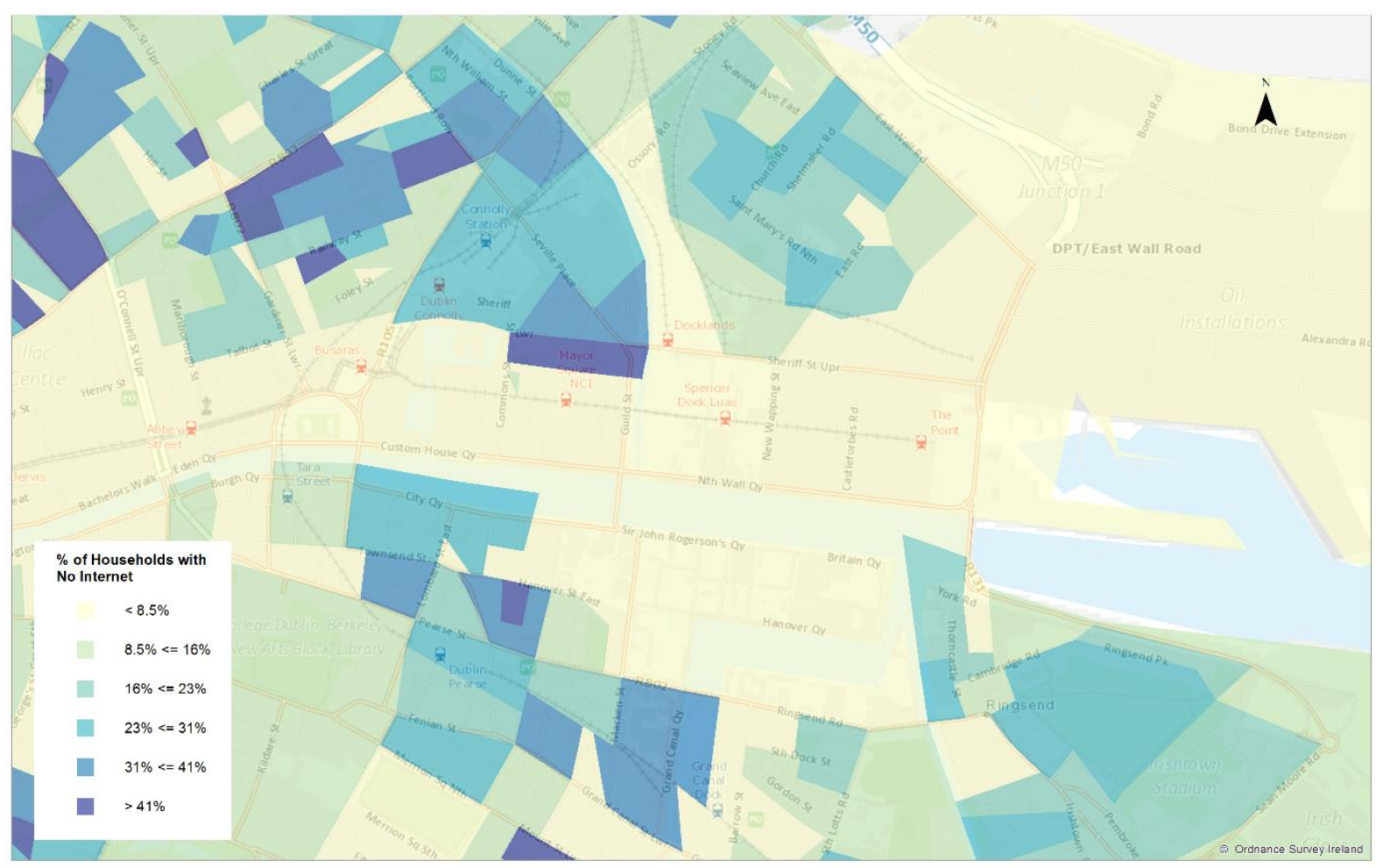

Figure 5: Percentage of households without internet access at the small area level (Source: Irish Census 2016 data from AIRO, Maynooth University).

The digital divide is most pronounced in Sheriff Street, where residents frequently use the local training centre for simple tasks like filling in online forms and sending job applications. With poor access to broadband and higher education, residents are less likely to be knowledgeable about the privacy implications of testbedding smart technologies in the area, and are removed from epistemic communities and advocacy coalitions (Kitchin et al., 2017) embroiled in smart city discourses in the city.

While Dublin has a reasonably equitable, if stressed public transport system, further digitisation of public life through smart phone apps for broker or sharing economy services may exacerbate existing divides. Online service brokers of global scale like Uber are increasingly seeking to make themselves 'essential', divesting patronage from communal transport (Wilkinson, 2017). The cult of the individual finds its way into routing apps like Waze that can divert users away from areas associated with crime or poverty, thereby further cloaking disadvantaged areas from critical eyes (cf. Graham and Marvin, 2001). Such landmarking bias is naturally already present in the marketing brochures of new residential development. For instance, the brochures for the 'Penthouses at Spencer Dock' denote the presence of notable tech and finance corporates, fashionable cafés and restaurants, and gyms. Such material is naturally less inclined to point out social housing and industrial heritage 
unless, like Kenny's house in a well-known satirical animation, it can be incorporated into standard vistas of elegant al fresco dining with sparkling delicate glassware.

The provision of wayfinding apps and the potential future provision in Dublin of digital kiosks with free high-bandwidth WiFi and USB charging ports are typically associated with the secondary benefits of consumer profiling based on interactions and tracking movements in space and time. As a form of infrastructure, it is parasitic on the provision of real assets to which it can direct attention, and when allied to nudging strategies and personalised advertising, akin to digital panhandling. Its 'fine-grained' services are consumer-centric rather than citizen-agnostic (Gardner and Hespanhol, 2017: 5), and are built on individually rated relationships between consumer and provider rather than equitable anonymity with stringent regulatory oversight.

\section{Infrastructural interdependencies between hard and soft urban technologies}

If we are to subsume the smart city into a broader discussion on urban technologies we must interrogate more closely the interdependencies between digital innovations and the material environment (cf. Ersoy, 2017). In the absence of critical discourse, smart city coalitions of actors may enrol cities into the form of low-regulation, splintered neoliberal economy (Graham and Marvin, 2001; Marvin et al., 2016) we see in cities which do not provide equitable services in the sense familiar to citizens of European social democracies. Rather than increase raise the water table of quality-of-life for all citizens, it instead endorses systems of privilege and divisions which can be exploited by populists as the backlash ensues.

In the UK, post-EU referendum political instability and the exclusionary nationalism it now evinces can be linked to its rapid dismantling of industrial capacity, its dependency on foreign investment and capital, and the expanding wealth gap between its poorest and wealthiest citizens (Becker et al., 2016; Goodwin and Heath, 2016; Gray et al., 2015). While Ireland is characterised by its emphasis on social cohesion alongside similarly marketoriented policies (Kitchin et al., 2012), it is nevertheless criticised for its "chronic underinvestment in infrastructure", with a commensurate need to dramatically increase investment to match population projections and restored economic growth (DKM Consultants, 2017). This, in turn, links to a lagging commitment from Ireland to meet its environmental objectives and embed efficiencies into all urban management and 
development. However, participants stressed that smart technologies were partly predicated on this demand for efficiency being already in place.

The bigger problem we are facing in Ireland is that compared to the continent and the European project we need to compete with all the other European cities. Infrastructure is very under developed in this country and people are not will to pay for it. [...] Smart probably doesn't solve anything because smartness is all about efficiency and there is no desire by the Irish people to be more efficient, they can afford it because it is a huge island with only 4 million people so there is no need to be very efficient in comparison to, if you look at Amsterdam. [...] There is no driving need here and that is where we are. (Interview SDD37, smart city researcher)

Yeah, I mean the problem generally with anything environmental is that the general public don't give a shit as a whole. Okay so you might, I might or whatever and they might recycle, but that's about as much. So like in terms of you will see stuff in the energy space and people will have these things around energy savings and stuff like that and people don't give a shit about saving energy. (Interview SDD22, innovation promoter)

Mapping out the technologies and infrastructures discussed by interview participants in the context of smart cities and place-making permits a tentative look at what can be considered as 'essential' infrastructure and that which is actively marketed as 'smart' based on the coding process (Table 1). 


\begin{tabular}{|c|c|}
\hline Infrastructure & Coding Frequency \\
\hline Public Transport (including Metro North and Dart Underground) & 30 \\
\hline Bridges & 29 \\
\hline Telco Infrastructure & 29 \\
\hline IoT and Sensors & 20 \\
\hline Hospitality & 20 \\
\hline Schools & 18 \\
\hline Drainage Sewerage & 18 \\
\hline Information & 17 \\
\hline Smart Lighting & 16 \\
\hline Regulations and Standards & 14 \\
\hline Human Tracking & 14 \\
\hline Parks & 13 \\
\hline Energy Generation and Management & 13 \\
\hline Shops and Retail & 13 \\
\hline Apps & 11 \\
\hline Theatres & 11 \\
\hline Heritage artifacts & 11 \\
\hline Housing Provision & 11 \\
\hline Flood monitoring & 9 \\
\hline Resource Sharing / Gig Economy & 9 \\
\hline Playgrounds & 9 \\
\hline Personalised Transport & 8 \\
\hline Data Accumulation & 7 \\
\hline Control Centres / Integration & 6 \\
\hline Museums & 6 \\
\hline Lesiure Facilities & 5 \\
\hline Creative / Makers & 5 \\
\hline Data Analytics & 5 \\
\hline Concert Venues & 4 \\
\hline Festivals & 4 \\
\hline Human Nudging & 3 \\
\hline Retail and Delivery & 3 \\
\hline Service Delivery & 3 \\
\hline Data Activitation & 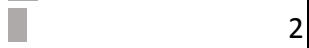 \\
\hline Libraries & 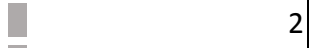 \\
\hline Allotments & 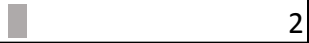 \\
\hline
\end{tabular}

Table 1: Key infrastructures and technologies discussed by participants.

When the relationship between smart technologies and urban form is restrained to the core definition of smart city technology as sensor networks, then it may be that urban form is no more amenable to being reshaped than forest pines are to Christmas tree lights. However, when opened to all forms of physical and digital urban technologies, wayfinding and telco tend to take a backseat next to harder-to-do items such as mega-infrastructure projects. In Dublin, this includes two deferred underground transport projects (Dart Underground and Metro North) repeatedly shelved by ministers fearing a rural backlash given the increasing dominance of the capital in the national economy.

A remaining task, then, is to sequence and integrate the provision of such technologies in a manner that meets societal objectives as laid down in city development plans and local area 
plans. Design thinking is slowly merging with smart city discourses through both general conceptual development of the smart city (Picon, 2015) and local-level experimentalism (Gardner and Hespanhol, 2017). The City Protocol framework for the ontology, liveability, and metrics of the smart city mark a conceptual growth from the ideals of place-based planning that have long been practiced in Barcelona, yet are wedded to an increasing technicism and a cybernetic vision of cities updated for the present age. In contrast, Gardner and Hespanhol (2017) outline a multi-scalar framework which includes both the individual and personal scales, alongside the metropolis and the neighbourhood. The individual scale can be separated from the personal scale, addressing ethical issues on the right to access and shape infrastructure (Antoniadis and Apostol, 2014; Corsín Jiménez, 2014).

These linkages between physical scales, urban densities, and hard and soft urban technologies are difficult to represent in the models of urban stacks (Zygiaris, 2013) favoured by digital technologists, trained and accustomed to using the Open Systems Interconnection model for computing. As a starting point, the analysis of existing data assemblages (Kitchin and Lauriault, 2014) may help, where relatively mature or maturing socio-technical systems are examined with attention to epistemic communities, places and practices, and political economy. Systems such as transport, when stripped of smart city hype, evidence progressive piecemeal development and are characterised by hard and soft technology assemblages, wherein data-driven organisational and behavioural change is manifestly visible. Transport modelling is an example of a soft urban technology that shapes the design and performance of hard infrastructure to ensure higher levels of service provision in the future.

Where transport is characterised by centralised control and limited participatory design, urban planning in the wider sense is shaped by a larger constellation of actors with frequently conflicting goals in which the central planning function is that of leadership, coordination, and regulation. Participation in planning from the wider implicated public is furthered through the provision of public planning databases such as www.myplan.ie, and through digital participation platforms where interested parties can provide direct feedback on city plans. Data on social exclusion and poverty such as that visualised in the AIRO (All-Island Research Observatory) mapping tool (http://airo.maynoothuniversity.ie) can inform social policy-making, which feed into planning and design decisions. Finally, the standard panoply of sensing infrastructures generally implied in smart city programmes, including digital kiosks, can also be mobilised to gather data and track behaviour to meet planning priorities, 
improve service provision, reduce inequalities, facilitate citizen science initiatives, as well as stimulate economic development.

\section{Conclusion}

Interfaces and divisions in cities are considered natural and inevitable by economists such as Hayek and Friedman (Mizouka, 2013: 89). This is not the case in social democratic polities such as the Ajuntament de Barcelona, nor in many other European cities, where multi-scalar, hierarchical planning can address divisions at the appropriate scale, such as through neighbourhood revitalisation and the softening of interfaces between contrasting neighbourhoods.

Ireland is in a transitional space between its legacy as a poorly developed country to assuming its responsibilities as a more mainstream small and wealthy European State, evident through its relatively late development of statutory planning (O’Leary, 2014) and its former ideological passivity to managed urbanisation as an inherent good. As in Barcelona, the smart cities programme in Dublin is part of a broad community of technologists, thinkers, and urban planners, in which the standard roll-out of sensor networks and integrated systems works increasingly in hand with urban development. The choice of the smart district is due not only to the multitude of global firms resident in the area, but also due to the previous special purpose planning vehicle which delivered integrated planning with high urban design and a degree of concern for social inclusion. While this planning arrangement partly continues through the Strategic Development Zone, the place of design and inclusion is now driven more by wider city priorities, themselves partly shaped by the pioneering nature of the Docklands development. This may leave a vulnerability through which soft urban technologies may exacerbate social divisions if they are installed without due concern to the interdependencies between hard and soft urban technologies and the divisions and social interfaces they co-shape.

The rationale of smart technologies is partly predicated on the generation of efficiencies in service provision, which itself is dependent on a culture of efficiency and sustainability being embedded into all area of urban and national life. The smart city is already proving a useful vehicle to push pan-European sustainable economic development, which in partnership with other parts of the globe may facilitate a rapid transition to a low-carbon world. Smart technologies in the absence of these shared goals may perform a parasitic role of redirecting the redistribution of limited resources to those who least need them, facilitating a cult of the 
individual and a corresponding poor sense of collective responsibility. This dynamic can also be registered in urban form, such as the stark contrasts of Silicon Valley and the encroachment of a hugely successful tech sector into housing and transport provision, arguably to the detriment of the common good (Waters, 2017). In contrast, design sensibility and social engagement, when translated into urban form and service provision, may work against the 'autistic architecture' of corporate development with its sterile public spaces and playgrounds for conspicuous consumption (Kaika, 2011). The entrepreneurial urbanism of the present may then cede space to richer, more confident, smart urbanism when the smart city is allied to more intellectually stimulating visions of future urban living.

\section{Acknowledgements}

The research for this paper was provided by a European Research Council Advanced Investigator Award, 'The Programmable City' (ERC-2012-AdG-323636).

I would like to thank Réka Péterscák for her role in gathering the data which informs this and other forthcoming outputs, and Rob Kitchin, Sung Yueh-Perng, and Claudio Coletta for their feedback on earlier drafts of this paper. I also express my gratitude to Margo Boenig-Liptsin and the CSI at MinesParisTech, for their critical feedback to a draft discussed during the Franco-Irish Ulysses academic interchange programme funded by the Irish Research Council and the Ministère de l'Europe et des Affaires étrangères.

\section{References}

Antoniadis P and Apostol I (2014) The Right(s) to the Hybrid City and the Role of DIY Networking. The Journal of Community Informatics 10(3).

Bartley B (2007) Planning in Ireland. In: Kitchin R and Bartley B (eds), Understanding Contemporary Ireland. London: Pluto, London: Pluto Press, pp. 31-43.

Becker SO, Fetzer T and Novy D (2016) Who Voted for Brexit? A Comprehensive District-Level Analysis. Available from: http://ukandeu.ac.uk/wp-content/uploads/2016/10/Who-voted-for-Brexit.pdf (accessed 10 November 2016).

Blok A and Farías I (eds) (2016) Urban cosmopolitics: agencements, assemblies, atmospheres. Questioning cities, New York, NY: Routledge.

Boyd R (1990) Realism, Approximate Truth and Philosophical Method. In: Savage W (ed.), Scientific Theories, Minneapolis: University of Minnesota Press, pp. 253-289.

Brand R (2009) Urban Artifacts and Social Practices in a Contested City. Journal of Urban Technology 16(23): 35-60.

Brenner N, Madden DJ and Wachsmuth D (2011) Assemblage urbanism and the challenges of critical urban theory. City 15(2): 225-240.

Byrne M (2016) Entrepreneurial Urbanism After the Crisis: Ireland's "Bad Bank" and the Redevelopment of Dublin's Docklands: Entrepreneurial Urbanism After the Crisis. Antipode 48(4): 899-918.

Calzada I (2017) The Techno-Politics of Data and Smart Devolution in City-Regions: Comparing Glasgow, Bristol, Barcelona, and Bilbao. Systems 5(1): 18.

Calzada I and Cobo C (2015) Unplugging: Deconstructing the Smart City. Journal of Urban Technology 0(0): $1-21$. 
Caragliu A, Bo CD and Nijkamp P (2011) Smart Cities in Europe. Journal of Urban Technology 18(2): 65-82.

Casamor Maldonado C (2016) Barcelona. Gresham Hotel, Dublin. Available from: http://www.dublincity.ie/symposium-dublin-city\%E2\%80\%99s-public-realm (accessed 22 November 2017).

Coletta C, Heaphy L and Kitchin R (2017) From the accidental to articulated smart city: The creation and work of 'Smart Dublin'. Available from: https:/osf.io/preprints/socarxiv/93ga5/download?format=pdf (accessed 19 June 2017).

COMPETE (2006) The COMPETE Network: Final Report - Messages for Competitive European Cities. Sheffield. Available from: https://www.liverpool.ac.uk/media/livacuk/publicpolicypractice/images/9012_COMPETE.pdf (accessed 22 November 2017).

Corsín Jiménez A (2014) The Right to Infrastructure: A Prototype for Open Source Urbanism. Environment and Planning D: Society and Space 32(2): 342-362.

Cugurullo F (2016) Urban eco-modernisation and the policy context of new eco-city projects: Where Masdar City fails and why. Urban Studies 53(11): 2417-2433.

Cugurullo F (2017) Exposing smart cities and eco-cities: Frankenstein urbanism and the sustainability challenges of the experimental city. Environment and Planning A 0(0): 1-20.

Cullen M (2016) Cities on the path to 'smart': information technology provider interactions with urban governance through smart city projects in Dubuque, Iowa and Portland, Oregon. Doctoral Thesis, The London School of Economics and Political Science (LSE). Available from: http://etheses.lse.ac.uk/3392/ (accessed 7 June 2017).

Datta A (2015) The smart entrepreneurial city: Dholera and 100 other utopias in India. In: Marvin S, LuqueAyala A, and McFarlane C (eds), Smart Urbanism: Utopian Vision Or False Dawn?, Routledge, pp. 52-70.

Dawe SN and Paradice D (2016) A Systems Approach to Smart City Infrastructure: A Small City Perspective. In: Dublin, Ireland, p. 11. Available from: http://iot-smartcities.lero.ie/wp-content/uploads/2016/12/ASystems-Approach-to-Smart-City-Infrastructure-A-Small-City-Perspective.pdf (accessed 22 November 2017).

Dawe SN and Sankar CS (2016) Developing a smart city by operationalizing the co-creation of value model. Journal of Information Technology Case and Application Research 18(1): 37-49.

Dawson GM (1984) Defensive planning in Belfast. Irish Geography 17(1): 27-41.

DKM Consultants (2017) Enhancing Ireland's Infrastructure: Construction Industry Federation Report. Dublin, Ireland: Construction Industry Federation. Available from: https://cif.ie/wpcontent/uploads/2017/07/CIF-Enhancing-Irelands-Infrastructure-Report-LR.pdf (accessed 1 October 2017).

Dublin City Council (2014) North Lotts and Grand Canal Dock Planning Scheme 2014. Available from: http://www.dublincity.ie/main-menu-services-planning-urban-development-plans-local-areaplans/north-lotts-grand-canal-dock (accessed 11 January 2018).

Ersoy A (2017) Smart cities as a mechanism towards a broader understanding of infrastructure interdependencies. Regional Studies, Regional Science 4(1): 1-6.

Farías I and Bender T (eds) (2012) Urban Assemblages: How Actor-Network Theory Changes Urban Studies. London: Routledge.

Farías I and Blok A (2016) Technical democracy as a challenge to urban studies: Introduction. City 20(4): 539_ 548.

Fuller S (2012) CSI: Kuhn and Latour. Social Studies of Science 42(3): 429-434.

Gaffikin F, Karelse C, Morrissey M, et al. (2016) Making Space for Each Other: Civic Place-Making in a Divided Society. Belfast: Queen's University Belfast. Available from: https://pure.qub.ac.uk/portal/en/publications/making-space-for-each-other-civic-placemaking-in-adivided-society(202fab7c-da83-4ecb-80b0-2ea579464d2d).html (accessed 11 January 2018).

Gardner N and Hespanhol L (2017) SMLXL: Scaling the smart city, from metropolis to individual. City, Culture and Society 0(0): 1-8.

Giere RN (2005) Scientific Realism: Old and New Problems. Erkenntnis 63(2): 149-165.

Giffinger R and Pichler-Milanović N (2007) Smart cities: Ranking of European medium-sized cities. Vienna: Centre of Regional Science, Vienna University of Technology.

Gilbert Simondon (1958) Du Mode d'Existence des Objets Techniques. Paris: Aubier-Montaigne. 
Goodwin MJ and Heath O (2016) The 2016 Referendum, Brexit and the Left Behind: An Aggregate-level Analysis of the Result. The Political Quarterly 87(3): 323-332.

Graham S and Marvin S (2001) Splintering urbanism: networked infrastructures, technological mobilities and the urban condition. London: Routledge.

Gray E, Farrall S, Hay C, et al. (2015) Thatcher's Grandchildren: The Long Road to Inequality. Political Insight 6(1): 16-19.

Guallart V (2012) La ciudad autosuficiente: Habitar en la sociedad de la información. Barcelona: RBA Libros.

Guggenheim M (2016) Im/mutable im/mobiles. From the socio-materiality of cities towards a differential cosmopolitics. In: Farías I and Blok A (eds), Urban cosmopolitics: agencements, assemblies, atmospheres, Questioning cities, New York, NY: Routledge, pp. 63-81.

Haase T (2009) Divided City - The Changing Face of Dublin's Inner City. Dublin: Dublin Inner City Partnership. Available from: http://trutzhaase.eu/wp/wp-content/uploads/R_2009_Divided-City.pdf (accessed 21 November 2017).

Harding LJ (2002) The Socio-Economic Impact Of The IFSC On The Local Community. Dublin, National College of Ireland. Available from: http://trap.ncirl.ie/292/ (accessed 19 September 2016).

Harvey D (2002) From managerialism to entrepreneurialism: The transformation of urban governance in late capitalism. The blackwell city reader: 456-463.

Hebbert M (2006) Town planning versus urbanismo. Planning Perspectives 21(3): 233-251.

Hollands RG (2008) Will the real smart city please stand up? City 12(3): 303-320.

Hooydonk E van (2007) Soft Values of Seaports: A Strategy for the Restoration of Public Support for Seaports. Garant.

Houdart S and Minato C (2009) Kuma Kengo: An Unconventional Monograph. Editions Donner Lieu Paris. Hoyle BS (1989) The Port-City interface: Trends, problems and examples. Geoforum 20(4): 429-435.

Kaika M (2011) Autistic Architecture: The Fall of the Icon and the Rise of the Serial Object of Architecture. Environment and Planning D: Society and Space 29(6): 968-992.

Kincaid A (2006) Postcolonial Dublin: imperial legacies and the built environment. Minneapolis, MN: University of Minnesota Press.

Kitchin R (2014) The real-time city? Big data and smart urbanism. GeoJournal 79(1): 1-14.

Kitchin R and Lauriault TP (2014) Towards Critical Data Studies: Charting and Unpacking Data Assemblages and Their Work. SSRN Scholarly Paper, Rochester, NY: Social Science Research Network. Available from: http://papers.ssrn.com/abstract=2474112 (accessed 12 January 2016).

Kitchin R, O’Callaghan C, Boyle M, et al. (2012) Placing Neoliberalism: The Rise and Fall of Ireland's Celtic Tiger. Environment and Planning A 44(6): 1302-1326.

Kitchin R, Coletta C, Evans L, et al. (2017) Smart cities, epistemic communities, advocacy coalitions and the 'last mile' problem. it - Information Technology 0(0). Available from: https://www.degruyter.com/view/j/itit.ahead-of-print/itit-2017-0004/itit-2017-0004.xml (accessed 29 November 2017).

Latour B (2005) Reassembling the Social: An Introduction to Actor-Network-Theory. Clarendon lectures in management studies, Oxford; New York: Oxford University Press.

Latour B (2013) An inquiry into modes of existence: an anthropology of the moderns. Cambridge, Massachusetts: Harvard University Press.

Lawton P and Punch M (2014) Urban governance and the 'European City': ideals and realities in Dublin, Ireland. International Journal of Urban and Regional Research 38(3): 864-885.

Lynch M (2012) Self-exemplifying revolutions? Notes on Kuhn and Latour. Social Studies of Science 42(3): 449-455.

MacLaren A, Kelly S and MacLaran A (2014) Neoliberal urban policy and the transformation of the city: Reshaping Dublin. Springer.

Maguire M (1993) A Socio-Economic Analysis of the Dublin Protestant Working Class, 1870-1926. Irish Economic and Social History 20(1): 35-61.

March H and Ribera-Fumaz R (2016) Smart contradictions: The politics of making Barcelona a Self-sufficient city. European Urban and Regional Studies 23(4): 816-830.

Marvin S, Luque-Ayala A and McFarlane C (eds) (2016) Smart urbanism: utopian vision or false dawn? London; New York: Routledge. 
McDonald F (2017) Renovated crane a major part of Dublin's 'port-city integration'. The Irish Times. Available from: https://www.irishtimes.com/business/commercial-property/renovated-crane-a-major-part-ofdublin-s-port-city-integration-1.3265603 (accessed 21 November 2017).

McFarlane C and Söderström O (2017) On alternative smart cities. City 0(0): 1-17.

McGuirk PM and MacLaran A (2001) Changing approaches to urban planning in an 'entrepreneurial city': the case of Dublin. European Planning Studies 9(4): 437-457.

Mehlman J (1972) The 'floating signifier': from Lévi-Strauss to Lacan. Yale French Studies: 10-37.

Mizouka F (2013) Capitalist Regulation of Public Transport. In: Low N (ed.), Transforming urban transport: the ethics, politics and practices of sustainable mobility, Abingdon, Oxon; New York, NY: Routledge, pp. 85-110.

Moore N (2008) Dublin docklands reinvented: the post-industrial regeneration of a European city quarter. Dublin: Four Courts Pr Ltd.

Moore N (2012) Dublin Docklands Development Authority: A wind-up? Ireland after NAMA. Available from: https://irelandafternama.wordpress.com/2012/05/31/dublin-docklands-development-authority-a-windup/ (accessed 20 November 2017).

Murtagh B (2011) Desegregation and Place Restructuring in the New Belfast. Urban Studies 48(6): 1119-1135.

O'Carroll A and Bennett D (2017) The Dublin Docker: The Working Lives of Dublin's Deep-Sea Port. Newbridge, Ireland: Irish Academic Press Ltd.

O’Leary S (2014) Sense of Place: A History of Irish Planning. Dublin: The History Press.

Petty J (2016) The London Spikes Controversy: Homelessness, Urban Securitisation and the Question of 'Hostile Architecture'. International Journal for Crime, Justice and Social Democracy 5(1): 67.

Picon A (2015) Smart cities: a spatialised intelligence. Ad primers, Chicester: John Wiley.

Punch M (2006) The politics of memory: The socio-cultural contradictions of globalisation and urban regeneration in Dublin. Irish Geography 39(2): 194-198.

Rialtas na hÉireann (1997) Dublin Docklands Development Authority Act, 1997. 7. Available from: http://www.irishstatutebook.ie/eli/1997/act/7/enacted/en/print (accessed 19 September 2016).

Rossi A (1982) The architecture of the city. Cambridge, MA: MIT Press.

Shelton T, Zook M and Wiig A (2015) The 'actually existing smart city'. Cambridge Journal of Regions, Economy and Society 8(1): 13-25.

Stengers I (2005) The cosmopolitical proposal. In: Latour B and Weibel P (eds), Making things public: Atmospheres of democracy, Cambridge, MA: MIT Press, pp. 994-1003.

Swyngedouw E, Moulaert F and Rodriguez A (2002) Neoliberal Urbanization in Europe: Large-Scale Urban Development Projects and the New Urban Policy. Antipode 34(3): 542-577.

Verhoeven P (2010) A review of port authority functions: towards a renaissance? Maritime Policy \& Management 37(3): 247-270.

Wallace C (2017) Civil society in search of a state: Dublin 1898-1922. Urban History 0(0): 1-27.

Waters R (2017) The great Silicon Valley land grab. Financial Times. Available from: https://www.ft.com/content/82bc282e-8790-11e7-bf50-e1c239b45787 (accessed 24 November 2017).

Wiig A (2015) IBM's smart city as techno-utopian policy mobility. City 19(2-3): 258-273.

Wilkinson A (2017) Uber's 'disruption' is far from benign - but it's not too big to ban. The Guardian, 22nd November. Available from: http://www.theguardian.com/commentisfree/2017/nov/22/uber-disruptionban-london-sadiq-khan (accessed 25 November 2017).

Witte P, Slack B, Keesman M, et al. (2017) Facilitating start-ups in port-city innovation ecosystems: A case study of Montreal and Rotterdam. Journal of Transport Geography 0(0): 1-11.

Yaneva A (2009) Made by the Office for Metropolitan Architecture: an ethnography of design. Rotterdam: 010 Publishers.

Yaneva A (2017) Five Ways to Make Architecture Political: An Introduction to the Politics of Design Practice. London: Bloomsbury Academic.

Zammito JH (2004) A Nice Derangement of Epistemes: Post-positivism in the Study of Science from Quine to Latour. Chicago, IL: University of Chicago Press.

Zygiaris S (2013) Smart City Reference Model: Assisting Planners to Conceptualize the Building of Smart City Innovation Ecosystems. Journal of the Knowledge Economy 4(2): 217-231. 